University of Nebraska - Lincoln

DigitalCommons@University of Nebraska - Lincoln

Faculty Publications from the Harold W. Manter Laboratory of Parasitology

Parasitology, Harold W. Manter Laboratory of

2009

\title{
Coccidia (Apicomplexa : Eimeriidae) from the Lagomorph Lepus tolai in Mongolia
}

\author{
Scott Lyell Gardner \\ University of Nebraska - Lincoln, slg@unl.edu \\ Nathan A. Seggerman \\ University of Nebraska - Lincoln \\ Nyamsuren Batsaikhan \\ National University of Mongolia, microtusb@yahoo.com \\ Sumiya Ganzorig \\ Hokkaido University, ganzorig@vetmed.hokudai.ac.jp \\ David S. Tinnin \\ University of Nebraska - Lincoln, dtinnin@unlserve.unl.edu \\ See next page for additional authors
}

Follow this and additional works at: https://digitalcommons.unl.edu/parasitologyfacpubs

Part of the Parasitology Commons

Gardner, Scott Lyell; Seggerman, Nathan A.; Batsaikhan, Nyamsuren; Ganzorig, Sumiya; Tinnin, David S.; and Duszynski, Donald W., "Coccidia (Apicomplexa : Eimeriidae) from the Lagomorph Lepus tolai in Mongolia" (2009). Faculty Publications from the Harold W. Manter Laboratory of Parasitology. 124. https://digitalcommons.unl.edu/parasitologyfacpubs/124

This Article is brought to you for free and open access by the Parasitology, Harold W. Manter Laboratory of at DigitalCommons@University of Nebraska - Lincoln. It has been accepted for inclusion in Faculty Publications from the Harold W. Manter Laboratory of Parasitology by an authorized administrator of DigitalCommons@University of Nebraska - Lincoln. 


\section{Authors}

Scott Lyell Gardner, Nathan A. Seggerman, Nyamsuren Batsaikhan, Sumiya Ganzorig, David S. Tinnin, and Donald W. Duszynski 


\title{
COCCIDIA (APICOMPLEXA: EIMERIIDAE) FROM THE LAGOMORPH LEPUS TOLAI IN MONGOLIA
}

\author{
Scott L. Gardner, Nathan A. Seggerman, Nyamsuren Batsaikhan, Sumiya Ganzorig†, David S. Tinnin, and \\ Donald W. Duszynskił \\ Harold W Manter Laboratory of Parasitology, University of Nebraska State Museum, University of Nebraska-Lincoln, Lincoln, \\ Nebraska 68588-0514.e-mail: slg@unl.edu
}

\begin{abstract}
In 1999, a single specimen of the Tolai hare, Lepus tolai Pallas, 1778, from the Gobi region of Mongolia was examined and had a new species of eimerian parasite in its intestinal contents. Eimeria gobiensis n. sp. is relatively large; it possesses 2 oocyst walls and a very well-developed oocyst residuum. Oocysts of the new species possess a thick wall with a double layer, a massive 3-layered micropyle, and are ellipsoidal, with average length and width of the oocyst of $38.6 \times 24.2 \mu \mathrm{m}$, respectively. The range in measurements of these oocysts extends from 27.3 to $49.2 \mu \mathrm{m}$ in length by 18.8 to $32.5 \mu \mathrm{m}$ in width, with a length/width ratio $=1.6$; the oocyst residuumis is composed of a sub-spheroidal mass of small granules with an average size of $12.0 \times 11.0 \mu \mathrm{m}$; sporocysts are ovoidal with an average length $\times$ width of $15.0 \times 7.7 \mu \mathrm{m}$, respectively, and a range in length extending from 9.2 to $21.0 \mu \mathrm{m}$ by 5.0 to $12.0 \mu \mathrm{m}$ in width. In addition, each sporozoite has a large, medial, refractile body with an average size of $6.0 \times 5.0 \mu \mathrm{m}$.
\end{abstract}

During a preliminary survey of mammalian parasite biodiversity from central Mongolia in the summer of 1999, approximately 40 species of mammals were collected from several different habitat types, representing 15 different collecting localities. From this work, 1 specimen of the Tolai hare Lepus tolai Pallas, 1778 (a female) was collected in the vicinity of Ulziyt Uul (see below) in the Gobi desert and examined for parasites. Tinnin et al. (2002) provided a detailed description of the habitat and a list of mammals collected from the locality. Here, we describe the coccidia recovered from this host as a presumptive new species of Eimeria.

\section{MATERIALS AND METHODS}

During our work in 1999, all small mammals were caught using pitfall or Sherman live traps, while large mammals, including this hare, were shot. The results of the collection and identification of the mammals themselves have been published (Tinnin et al., 2002). Specimens were examined for parasites by the senior author in the field promptly after capture, following the methods outlined in Gardner (1996). Organs were examined for the presence of metazoan parasites; fecal pellets were removed from the lower bowel of each animal and preserved in $15 \mathrm{ml}$ Wheaton Snap Cap vials (available through Fisher Scientific, Pittsburg, Pennsylvania) containing about $5 \mathrm{ml}$ of $2 \%$ aqueous (w/v) potassium dichromate $\left(\mathrm{K}_{2} \mathrm{Cr}_{2} \mathrm{O}_{7}\right)$ solution (Gardner, 1996).

Upon return from Mongolia, samples were refrigerated at approximately $2 \mathrm{C}$ until they were studied. Oocysts found in the samples showed various stages of development, but most were completely sporulated. Close observation via standard differential interference contrast light microscopy at $\times 40$ and higher allowed us to distinguish a distinct oocyst morphotype in our samples. Oocysts were isolated and photographed as described by Duszynski and Wilber (1997). Our oocysts were measured using an integrated computerized system and photographed with a Zeiss Axiophot (Zeiss USA, http://www.zeiss.com), using Normarski-interference with a $\times 63$ objective oil immersion lens. In accordance with the guidelines suggested by Bandoni and Duszynski (1988), we submitted photomicrographs of the new eimerian to the Harold W. Manter Laboratory of Parasitology phototype collection, University of Nebraska-Lincoln, Lincoln, Nebraska; skin, skull, skeleton, and tissues of the symbiotype host for the new eimeriid species are preserved in the Mammal Division, Museum of Southwestern Biology, the University of New Mexico, Albuquerque, New Mexico. Abbreviations follow those of

Received 23 April 2009; revised 22 July 2009; accepted 23 July 2009.

* Department of Zoology, National University of Mongolia, Ulaanbaatar, Mongolia 210646, P.O. Box 348, Mongolia.

$\dagger$ Laboratory of Parasitology, Faculty of Veterinary Medicine, Hokkaido

University, Sapporo 060-0818, North 18, West 9, Hokkaido, Japan.

$\$$ Department of Biology, The University of New Mexico, Albuquerque, New Mexico 87131.

DOI: 10.1645/GE-2137.1
Wilber et al. (1998): length (L), width (W), micropyle (M), oocyst residuum (OR), polar granule (PG), Stieda body (SB), sub-Stieda body (SSB), para-Stieda body (PSB), sporocyst residuum (SR), and refractile body (RB), but we use SZ for sporozoites. Measurements given include n = number of characters measured, followed by average length and width, standard deviation (SD), then range of length and width in parentheses. All measurements are in $\mu \mathrm{m}$. Comparative measurements are presented in Table I.

\section{DESCRIPTION}

Eimeria gobiensis n. sp.

(Figs. 1-10)

Diagnosis: Sporulated oocysts ellipsoidal and elongate $(\mathrm{n}=62) 38.6 \times$ $24.2(\mathrm{SD}=3.6 \times 2.2)(27.3-49.2 \times 18.8-32.5)$ with $\mathrm{L} / \mathrm{W}$ ratio of 1.60 ; wall $(\mathrm{n}=62) 2.1(\mathrm{SD}=0.5)(1.0-3.4)$ of uneven thickness composed of 2 layers: outer wall pale blue to transparent, smooth, $\sim 3 / 4$ of total thickness; inner layer yellow; PG absent, but M and OR are clearly present. The oocyst wall thickens near the margin of the prominent $\mathrm{M}$. Micropyle is triple layered and very thick. The OR $(n=50)$ is $12.1 \times 10.8$ $(\mathrm{SD}=1.5 \times 1.6)(10.3-18.4 \times 9.0-17.3)$; sporocysts $(\mathrm{n}=97)$ ovoid, tapered at 1 end, $15.0 \times 7.7(\mathrm{SD}=1.9 \times 1.0)(9.2-20.9 \times 4.9-11.7)$; $\mathrm{SR}$ absent; SB present at tapered end, but SSB and PSB are both absent; each SZ with 1, large posterior RB $(\mathrm{n}=193) 6.1 \times 4.8(\mathrm{SD}=1.1 \times 1.0)(3.9$ $11.0 \times 2.6-8.0$ ). Age of oocysts at time of study, calculated from time of collection to the date of isolation, was 3,343 days.

\section{Taxonomic summary}

Symbiotype host: Lepus tolai Pallas, 1778, Museum of Southwestern Biology, Division of Mammals, No. 94357, NK 100752 (female, approximately $2 \mathrm{yr}$ of age) (see Frey et al., 1992).

Type locality: Vicinity of Ulziyt Uul, Mongolia, 1,640 m altitude $\left(44^{\circ} 41^{\prime} 09^{\prime \prime} \mathrm{N}, 102^{\circ} 00^{\prime} 57^{\prime \prime} \mathrm{E}\right)$

Prevalence: One of 1 (100\%) Lepus tolai.

Site of infection: Unknown; oocysts recovered from feces.

Material deposited: Syntypes (=phototypes, see Bandoni and Duszynski, 1988) of sporulated oocysts, HWML Coll. No. 49155.

Etymology: The name "Eimeria gobiensis" is derived from the locality in which this specimen's symbiotype host was collected; "gobiensis" is indicative of the Gobi desert region of Mongolia, meaning "of the gobi."

\section{Remarks}

Oocysts of this eimerian do not resemble those from any species previously described from leporids of Eurasia. Specifically, E. gobiensis can be distinguished from all similar species described from the Leporidae by the following: from E. hungarica Pellérdy, 1956; E. leporis Nieschulz, 1923; E. punjabensis Gill \& Ray, 1960; E. robertsoni Madsen, 1938; E. ruficaudatus Gill \& Ray, 1960; E. septentrionalis Yakimoff et al., 1936; and E. stefanskii Pastuszko, 1961, in having 2 distinct oocyst wall layers. Eimeria gobiensis also has a well-developed OR, whereas E. campania 


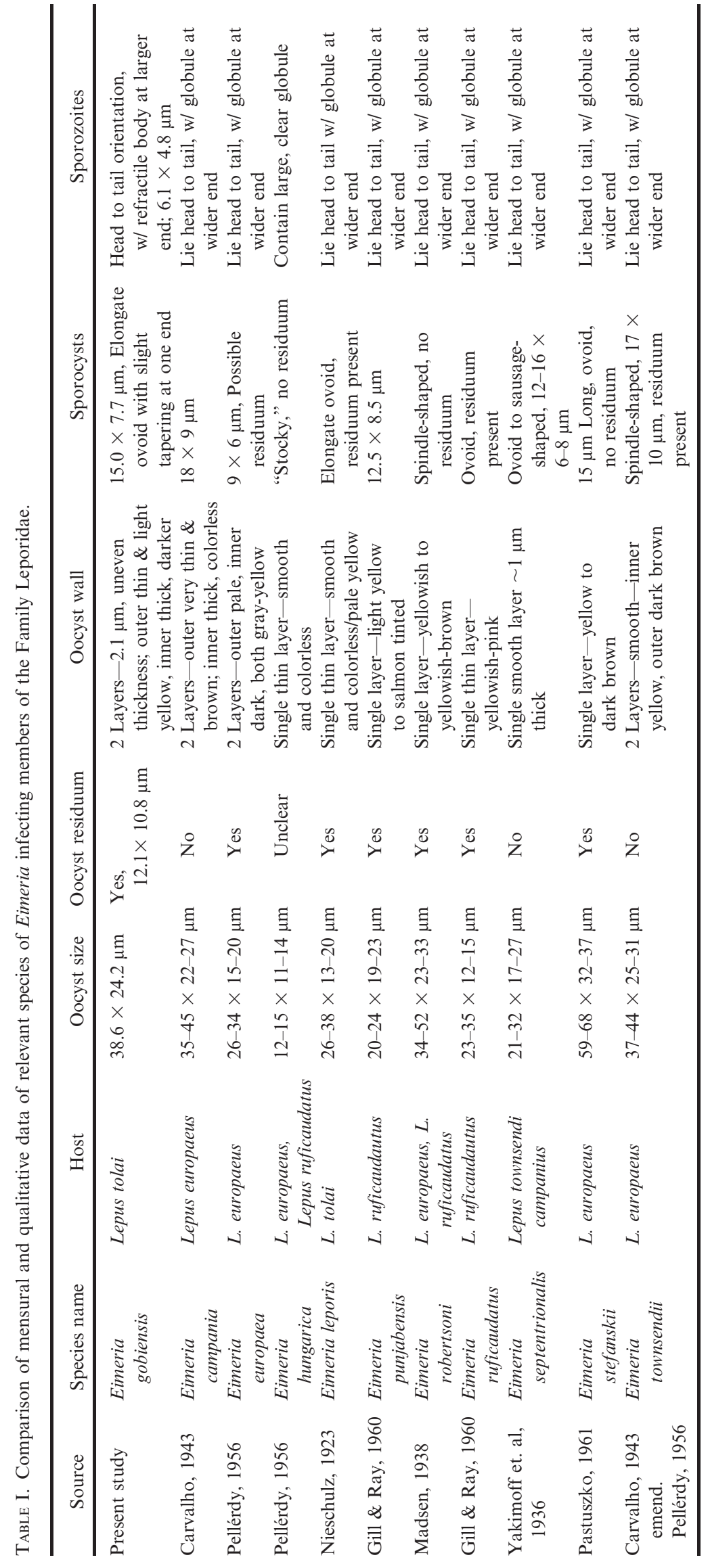



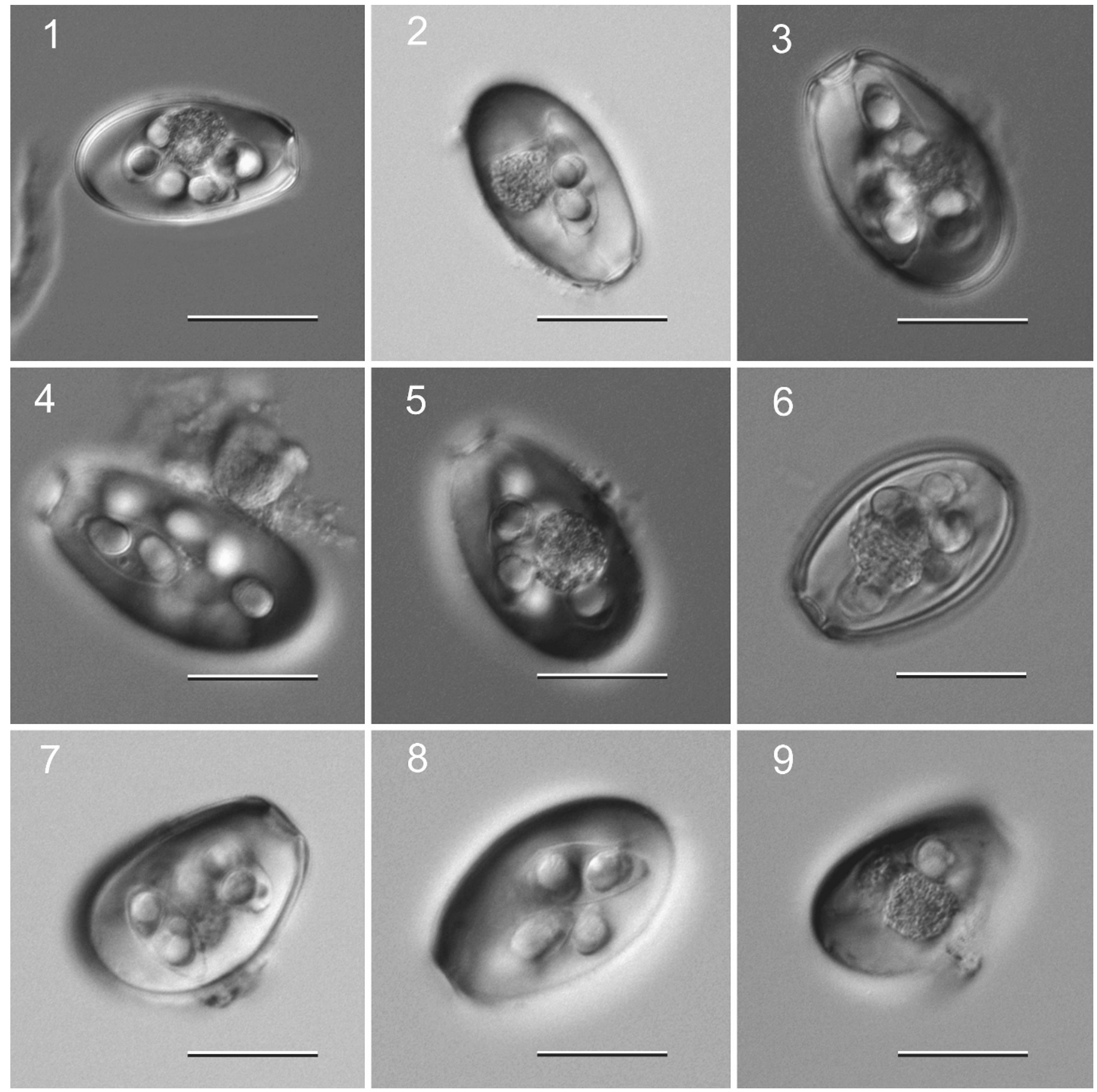

Figures 1-9. Photomicrographs of sporulated oocysts of coccidia recovered from the feces of Lepus tolai Pallas, 1778. Eimeria gobiensis n. sp. Note prominent oocyst residuum $(\mathbf{1}, \mathbf{2}, \mathbf{5}, \mathbf{6}, \mathbf{9})$, thick, bi-layered oocyst wall $(\mathbf{1}, \mathbf{6})$, long, tapered sporocysts, and head to tail orientation of sporozoites with large refractile bodies $(\mathbf{1}, \mathbf{4}, \mathbf{5}, \mathbf{7}, \mathbf{8})$, and prominent triple-layered micropyle $(\mathbf{1}, \mathbf{3}, \mathbf{6})$. Scale bar $=25 \mu \mathrm{m}$.

Carvalho, 1943, and E. townsendii (Pellérdy, 1956) have none. Finally, E. gobiensis can be distinguished from E. europaea Pellérdy, 1956 based on the size of the oocyst. In E. gobiensis, the average oocyst size is $38.6 \times 24.2$ vs. 26-34 × 15-20, respectively.

\section{DISCUSSION}

Species of Eimeria are common in lagomorphs globally; consequently, the presence of coccidia in L. tolai from Mongolia is not surprising. While the locality from which the parasite specimens were obtained is superficially similar in an ecological sense to regions in central North America, their inherent isolation from these populations presents new opportunities for study. Although beginning work has been conducted to document the biodiversity of mammals and their parasites in Mongolia and central Asia, the actual extent of the literature and studies available is woefully deficient compared to other areas of the world. Research institutes from Mongolia, Russia, and Germany have made progress in the latter half of the 20th century in 


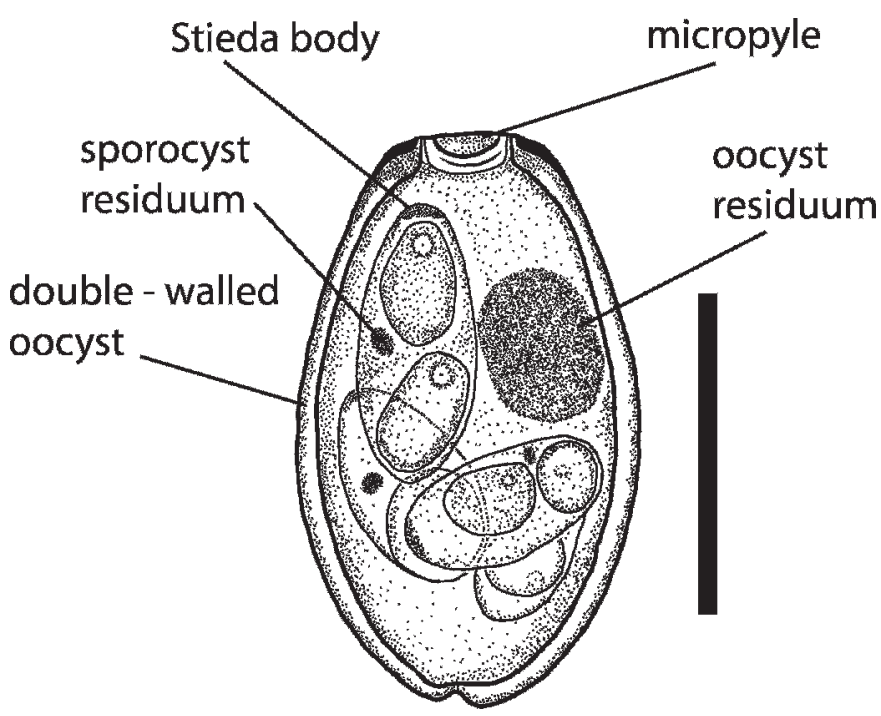

FIGURE 10. Line drawing of Eimeria gobiensis n. sp. with major structures in the oocyst labeled. Scale bar $=25 \mu \mathrm{m}$.

documenting the mammalian fauna of Mongolia, but there are still several areas, i.e., parasitology, that are very poorly known.

Since this report is based on a very short field expedition with limited time for collecting a larger series of mammals, we expect that results from our continuing work in Mongolia will provide more data on prevalence and diversity of eimerian species in these mammals.

\section{ACKNOWLEDGMENTS}

This work was supported by NSF grants DEB-0717214, DEI-0646356, DBI-9631295, and DBI-9411976. Additionally, we thank Gabor Racz, Ethan Jensen, and Agustin Jimenez for assistance with microscopy, photomicrography, and general support during this work.

\section{LITERATURE CITED}

Bandoni, S. M., And D. W. Duszynski. 1988. A plea for improved preservation of type material for coccidia. Journal of Parasitology 74: 519-523.

Carvalho, J. M. 1943. The coccidia of wild rabbits of Iowa. Iowa State College Journal of Science 18: 103-135.

Duszynski, D. W., And P. G. Wilber. 1997. A guideline for the preparation of species descriptions in the Eimeriidae. Journal of Parasitology 83: 333-336.

Frey, J. K., D. W. Duszynski, W. L. Gannon, T. L. Yates, and S. L. GARDNER. 1992. Designation and curation of type host specimens (Symbiotypes) for new parasite species. Journal of Parasitology 78: 930-932.

Gardner, S. L. 1996. Essential techniques for collection of parasites during surveys of mammals. In Measuring and monitoring biological diversity_-Standard methods for mammals, D. Wilson, R. Cole, J. D. Nichols, R. Rudran, and M. Foster (eds.). Smithsonian Institution Press, Washington, D.C., p. 291-298.

GILl, B. S., AND H. N. RAY. 1960. The coccidian of the domestic rabbit and the common field hare of India. Proceedings of the Zoological Society (Calcutta) 13: 128-143.

MAdSEN, H. 1938. The coccidia of the east Greenland hares with a revision of the coccidia of hares and rabbits. Meddelelser om gronland udgivn af Kommissionen for videnskabelige undersogelser I gronland 16: 138 .

Nieschulz, O. 1923. Uber Hasenkokzidien (Eimeria leporis n. sp). Deutsche Tierarztliche Wochenschrifte 31: 245-247.

Pastuszko, J. 1961. W sprawie odrebnosci gatunkow rodzaju Eimeria pasozytujacych u krolikow I zajecy. Wiadomosci Parazytologiczne 7: 305-307.

Pellérdy, L. 1956. On the status of the Eimeria species of Lepus europaeus and related species. Acta Veterinaria Academia Scientiarum Hungaricae 6: $451-467$

Tinnin, D. S., J. L. Dunnum, J. S. Bravo, N. Batsaikhan, M. S. Burt, S. L. Gardner, and T. L. Yates. 2002. Contributions to the mammalogy of Mongolia, with a checklist of species for the country. Special Publications of the Museum of Southwestern Biology 6: 1-38

Wilber, P. G., D. W. Duszynski, S. J. Upton, R. S. Seville, and J. O. Corliss. 1998. A revision of the taxonomy and nomenclature of the Eimeria spp. (Apicomplexa: Eimeriidae) from rodents in the Tribe Marmotini (Sciuridae). Systematic Parasitology 39: 113-135.

Yakimoff, W. L., S. N. Matschoulsky, and O. A. Spartansky. 1936. Neue Koksidie der Hasen. Wiener Tierarztliche Monatsschrift 23: 490-491. 